\title{
Identifikasi Akuifer Air Asin Dan Air Tawar Berdasarkan Model Tahananjenis Dan Data Bor Di Sidoarjo, Jawa Timur
}

\author{
Hena Dian Ayu ${ }^{1,}$ Akhmad Jufriadi ${ }^{1^{*}}$ \\ ${ }^{1}$ Program Studi Pendidikan Fisika, Universitas Kanjuruhan Malang
}

\begin{abstract}
ABSTRAK Penelitian ini bertujuan untuk melakukan identifikasi akuifer air asin dan air tawar di daerah Sidoarjo. Penentuan akuifer dilakukan berdasarkan model tahananjenis 2D dan data bor. Interpretasi data tahananjenis menunjukkan bahwa prospek akuifer air tawar ada pada kedalaman 10 hingga 50 meter yang menyebar luas, dan akuifer air tawar dalam berada pada kedalaman 140 sampai 170 meter. Akuiferakuifer tersebut memiliki nilai tahananjenis antara 14,7 sampai 46,2 ohm-meter. Akuifer air asin teridentifikasi pada kedalaman 51 sampai 110 meter dengan nilai tahananjenis 0,48 sampai 3,1 ohm-meter, dan air payau pada kedalaman 20 hingga 40 meter.
\end{abstract}

Kata Kunci : geolistrik, data bor, air asin, air tawar, Sidoarjo.

\begin{abstract}
Identification Of Salt And Fresh Water Aquifers Based On Resistivity Model And Logging Data In Sidoarjo, East Java. The purpose of this study is to identify saltwater and freshwater aquifers in Sidoarjo region. The aquifers were identified based on a $2 D$ resistivity modeling from geoelectrical survey and data interpretation from resistivity logging. Analyzes from both data show that the freshwater aquifer is at the depth of 10 to 50 meters, which are widespread. A deep freshwater aquifer is in a depth of 140 to 170 meters. These aquifers has a resistivity value between 14.7 to $46.2 \mathrm{ohm}$-meters.
\end{abstract}

$\begin{array}{ll}\text { Naskah masuk } & : 24 \text { April } 2019 \\ \text { Naskah direvisi } & : \text { 15 September } 2019 \\ \text { Naskah diterima } & : \text { 11 Desember } 2019\end{array}$

*Penulis korespondensi

Email : akhmadjufriadi@unikama.ac.id
Saltwater aquifers are identified in the depth of 51 to 110 meters with resistivity values of 0.48 to 3.1 ohms-meters. And brackish water is at the depth of 20 to 40 meters.

Keywords : geoelectric, logging, salt water, fresh water, Sidoarjo.

\section{PENDAHULUAN}

Daerah pesisir merupakan daerah dinamis, dimana akuifer air tawar berinteraksi dengan akuifer air asin. Lokasi akuifer air asin dan air tawar ditentukan oleh sifat kepadatan dan tekanan pada dua sisi akuifer dan sifat hidrologi bawah permukaan yang mengontrol pergerakan fluida (Goebel, Pidlisecky, \& Knight, 2017), seperti kemampuan air meresap melalui celah lapisan batuan, gaya kapilaritas yang memungkinkan air bergerak ke atas melalui pori-pori batuan. Interaksi yang terjadi tersebut akan menyebabkan gangguan kesetimbangan air bawah tanah dan menyebabkan intrusi air laut terhadap akuifer air tanah (Shakoor et al., 2017). Intrusi air laut adalah masuknya air laut menembus akuifer air tawar, sehingga akuifer air tawar menjadi akuifer air payau dan asin (Herdyansah \& Rahmawati, 2017). Hal tersebut merupakan fenomena yang sering dijumpai di daerah pesisir, dan salah satu hal yang tidak dapat dihindarkan, karena daerah pesisir berbatasan langsung dengan daerah pantai (Hodlur, Dhakate, \& Andrade, 2006; Utomo, 2011).

Salah satu daerah pesisir di Indonesia yang mengalami perkembangan pesat setelah menjadi kawasan industri adalah Kabupaten Sidoarjo. Perkembangan tersebut dikuti oleh pertumbuhan penduduk sebesar $2,84 \%$ per tahun dengan perkiraan mencapai 271.557 jiwa pada tahun 2022. Pertumbuhan penduduk meningkatkan kebutuhan air bersih dari 226,74 liter per detik pada tahun 2016 menjadi 477,09 liter per detik pada tahun 2022 (Novianto \& Nurhayati, 2013). 
Dalam rangka pemenuhan kebutuhan air bersih tersebut, maka eksplorasi air bersih dengan menentukan akuifer air asin dan air tawar secara akurat sangat penting dilakukan.

Identifikasi sederhana dilakukan dengan pengambilan sampel air dan pengamatan pada air sumur yang sudah ada. Pendekatan ini kurang efektif untuk menggambarkan kondisi akuifer air bawah tanah, karena hasil pengamatan pada air sumur hanya dilakukan pada titik-titik sumur tertentu saja dan mewakili kondisi akuifer di titik tersebut. Sehingga kondisi akuifer pada titik sumur tersebut tidak dapat dijadikan dasar untuk menggambarkan kondisi akuifer secara luas.

Metoda tahananjenis geolistrik menjadi pilihan utama dalam penyelidikan bawah permukaan dangkal (Martorana, Capizzi, Alessandro, \& Luzio, 2016), penyelidikan bawah tanah (Laxmi \& Ramadass, 2012) dan investigasi air bawah tanah (Khan, Waheedullah, \& Bhatti, 2013), serta untuk mengetahui kondisi hidrogeologi dan muka air bawah tanah (Kitila, Lemessa, Gebrekidan, \& Alamirew, 2013). Metode geolistrik sering digunakan karena adanya korelasi antara besarnya tahananjenis lapisan tanah bawah permukaan dengan kondisi geologi dan hidrogeologi air bawah tanah (Boubaya, 2017), adanya korelasi antara tahananjenis dengan parameter geologi lain seperti mineral batuan, fluida (Jufriadi \& Ayu, 2014), adanya korelasi antara tahananjenis porositas serta permeabilitas batuan (Helaly, 2017), adanya korelasi antara sebaran tahananjenis dengan jenis lapisan tanah (Pranata, Jufriadi, Ayu, \& Wahyuningsih, 2016), serta mudah dan efisien dalam pelaksanaan (Wiyono, Lailatin, \& Jufriadi, 2019). Metode geolistrik juga merupakan salah satu metode geofisika yang tidak merusak, menghasilkan data dengan jangkauan luas dengan cara cepat, dan tidak mahal (McInnis et al., 2013).

Pemetaan akuifer air asin dan air tawar dengan metode geolistrik sudah umum dilakukan (e.g. Alabjah, Amraoui, Chibout, \& Slimani, 2018). Pada kasus akuifer air tawar, hasil interpretasi data tahananjenis geolistrik memberikan hasil yang bagus karena tahananjenis akuifer air tawar secara signifikan lebih tinggi dari pada akuifer air asin. Namun ketika air asin mendominasi masuk menembus akuifer air tawar pada daerah pesisir, maka interpretasi data geolistrik akan memberikan hasil yang tidak akurat (Hodlur et al., 2006).
Metode lain yang sering digunakan untuk penyelidikan kondisi bawah permukaan adalah dengan interpretasi data tahananjenis bor. Interpretasi data bor digunakan untuk menentukan akuifer air asin dan air tawar dengan lebih akurat (Hodlur et al., 2006), dan memberikan gambaran detail kondisi hidrogeologi bawah permukaan (Benjumea, Macau, Gabàs, \& Figueras, 2016). Namun, data bor sangat tidak efektif untuk penyelidikan dalam skala luas karena harus dilakukan pengeboran yang membutuhkan waktu lama dan biaya besar pada satu titik pengeboran.

Oleh karena itu, metode geolistrik array dapat dipadukan dengan data bor untuk menggambarkan kondisi bawah permukaan, dan identifikasi akuifer air asin dan air tawar secara akurat dan dalam skala luas. Tujuan utama dari penelitian ini adalah melakukan identifikasi terhadap akuifer air asin dan air bersih di daerah penelitian, yang dapat digunakan sebagai dasar eksplorasi akuifer air bawah tanah untuk memenuhi kebutuhan masyarakat yang sangat tinggi.

\section{Lokasi Penelitian}

Penelitian dilakukan di Sidoarjo, Provinsi Jawa Timur (Gambar 1). Secara geografis, Sidoarjo terletak pada $112,5^{\circ}-112,9^{\circ}$ Bujur Timur dan $7,3^{\circ}$ $7,5^{\circ}$ Lintang Selatan. Sebagian besar wilayahnya berada pada ketinggian 3-7 mdpl pada bagian tengah, daerah pantai dan tambak dengan ketinggian 0-3 mdpl. Kondisi geologi daerah Sidoarjo terdiri atas lajur Pegunungan Selatan (terbentuk oleh gamping dengan intrusi batuan beku dan aliran lava yang mengalami tekanan), lajur Rembang (terbentuk dari lempung napalan dan gamping yang merupakan cekungan minyak dan gas bumi), lajur Kendeng (tersusun atas lempung dan Pasir), lajur Gunung Api Tengah (terbentuk oleh endapan material Gunung Api). Secara umum terdiri atas endapan alluvium, batuan gunung api kuarter atas, tuf pasiran dan batuan gunung api kuarter tengah (Budiono, Handoko, Hernawan, \& Godwin, 2010).

Berdasarkan peta geologi dan hidrogeologi (Gambar 1), batuan penyusun wilayah Sidoarjo terdiri atas endapan aluvial, dan daerah akuifer produktif sedang dengan penyebaran luas. Secara khusus, daerah penelitian merupakan dataran rendah dengan dominasi endapan alluvium terdiri dari pasir, kerikil, kerakal dan lempung (Qa). 


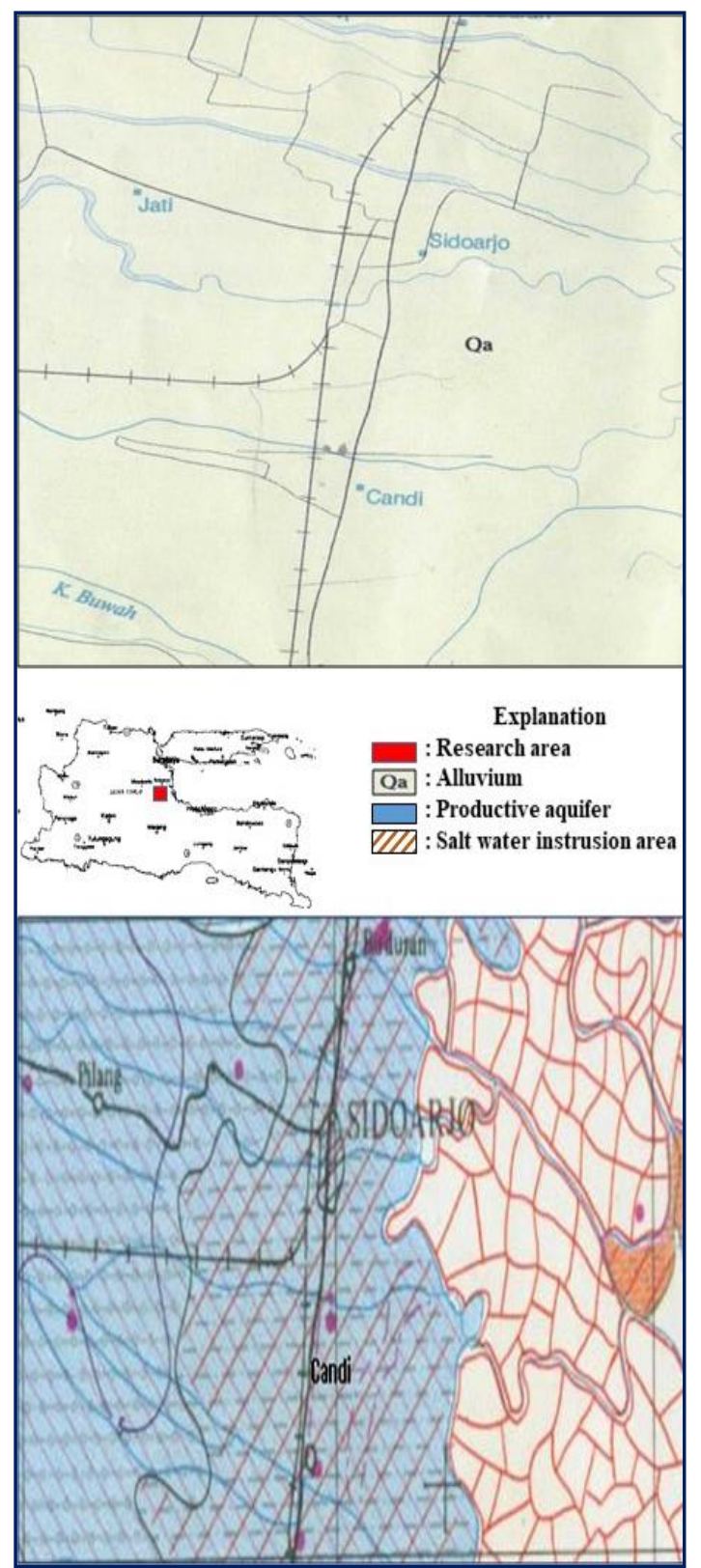

Gambar 1. Kondisi geologi dan hidrogeologi

Aluvium merupakan batuan muda yang diendapkan secara luas di daerah Sidoarjo.

\section{METODE}

Identifikasi akuifer air asin dan air tawar dilakukan dengan interpretasi data geolistrik 2D dan bor. Hasil interpretasi tersebut juga dipadukan dengan data kondisi akuifer sumur di sekitar lokasi penelitian.

Akusisi data geolistrik dilakukan pada 98 titik pengukuran dengan konfigurasi Wenner desain 2 dimensi, dan jarak antar elektroda adalah 40 meter. Pengolahan data dilakukan dengan

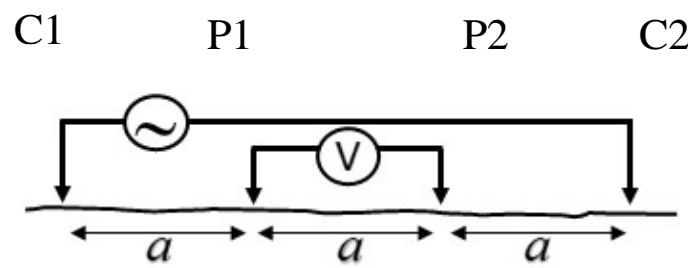

Gambar 2. Konfigurasi Wenner

menggunakan program RES2DINV, yang menghasilkan gambaran penampang lapisan bawah permukaan dengan jelas (Torleif Dahlin \& Bing, 2004).

\section{Geolistrik Tahananjenis}

Secara umum, tahapan dalam penerapan metode geolistrik adalah tahapan akuisisi, pengolahan, dan interpretasi data.

Akuisisi data geolistrik dilakukan dengan injeksi arus listrik ke dalam bumi melalui dua elektroda, kemudian beda potensial diukur melalui dua elektroda potensial lainnya. Terdapat beberapa konfigurasi elektroda dalam akuisisi data yang dapat digunakan dalam akuisisi geolistrik, antara lain konfigurasi schlumberger, dipole-dipole, pole-dipole, dan wenner. Dalam penelitian ini digunakan konfigurasi wenner dengan model desain 2D. Desain 2D cukup memberikan gambaran detail kondisi lapisan bawah permukaan secara vertikal maupun horizontal (Ayolabi, Folorunso, Odukoya, \& Adeniran, 2013). Pemodelan tahananjenis 2D memberikan hasil representasi geologi yang lebih baik dari pada desain vertikal sounding maupun lateral mapping (Dahlin \& Loke, 1998). Karena vertikal sounding hanya mampu mengetahui distribusi nilai tahananjenis pada suatu titik target secara vertikal, dan lateral mapping hanya mampu mengetahui sebaran nilai tahananjenis secara horizontal pada titik target kedalaman tertentu. Sedangkan desain 2D menghasilkan distribusi nilai tahananjenis secara vertikal dan horizontal.

Susunan elektorode konfigurasi wenner ditunjukkan pada Gambar 2. Jarak antara elektroda arus $1(\mathrm{C} 1)$ - elektroda potensial 1 (P1) 


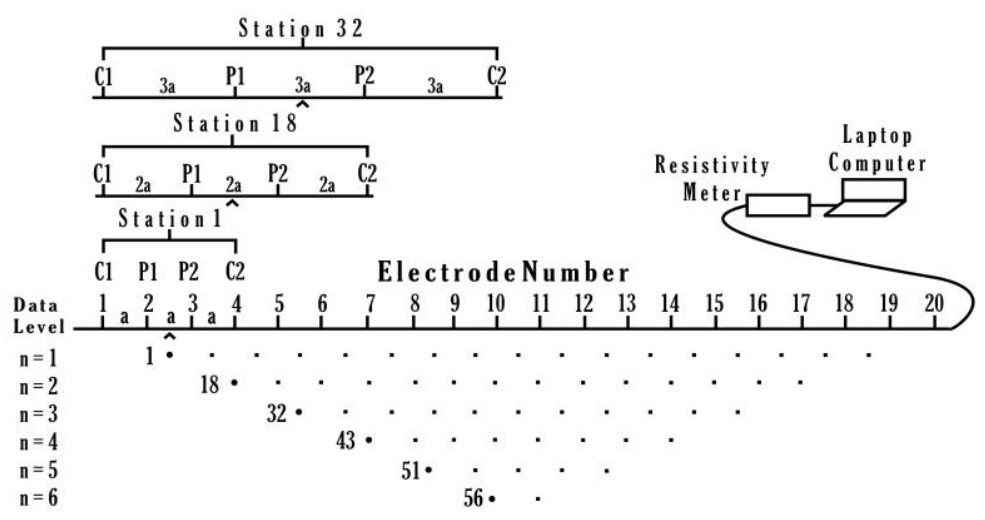

Gambar 3. Desain survei 2D konfigurasi Wenner (Loke, 2013)

- elektroda potensial 2 (P2) - elektroda arus 2 (C2), masing-masing spasi $\boldsymbol{a}$, adalah sama.

Akuisisi data dengan konfigurasi wenner model desain 2D (Gambar 3) dilakukan dengan posisi awal elektrode C1-P1-P2-C2 secara berurutan

Variasi harga tahananjenis masing-masing lapisan titik ukur ditentukan dengan mengukur arus dan beda potensial untuk setiap jarak tertentu, dan variasi jarak elektroda arus dan potensial (faktor geometri). Secara umum kondisi lapisan tanah bawah permukaan digambarkan melalui penampang tahananjenis (Metwaly \& Alfouzan, 2013). Hubungan antara tahananjenis semu, arus, tegangan dan faktor geometri, dinyatakan dalam persamaan berikut (Loke, 2013):

$$
\rho_{a}=2 \pi a \frac{V}{I}=K \frac{V}{I}
$$

dimana $\rho_{a}$ adalah tahananjenis semu $(\Omega \mathrm{m}) ; a$ adalah spasi elektrode; $K$ adalah faktor geometri; $V$ adalah tegangan; dan $I$ adalah arus.

Nilai tahananjenis semu adalah nilai tahananjenis yang sama dari lapisan tanah homogen. Untuk mendapatkan nilai tahananjenis sesungguhnya, dilakukan pendekatan dengan metode inversi kuadrat terkecil berdasarkan teknik optimasi quasi-Newton dengan menggunakan program RES2DINV (Loke \& Barker, 1995).

\section{Pengeboran (Logging)}

Pengeboran dilakukan untuk menghasilkan beberapa data geofisika vertikal. Setelah pengeboran, sensor geofisika dimasukkan ke berada pada posisi 1-2-3-4 untuk pengukuran pertama. Kemudian pengukuran kedua dilakukan dengan menggeser posisi elektode sejauh spasi $a$ sehingga elektrode C1-P1-P2-C2 berada pada posisi 2-3-4-5, demikian selanjutnya (Jufriadi \& Ayu, 2014).

dalam lubang bor untuk mencatat data logging. Data logging merupakan pengukuran parameter geofisika seperti nilai tahananjenis, spontaneous potential, dan temperatur pada lubang sumur relatif terhadap waktu dan kedalaman. Data logging tersebut menggambarkan hubungan antara kedalaman dengan jenis dan karakter batuan lapisan bawah permukaan. Seperti juga data tahananjenis pada umumnya, nilai tinggi pada data logging menunjukkan material seperti kuarsa dan muskovit, nilai sedang untuk material pasir, dan nilai rendah untuk clay dan akuifer air asin.

\section{HASIL DAN PEMBAHASAN}

\section{Model tahananjenis 2Dvitasti}

Hasil pengolahan data geolistrik tahananjenis adalah penampang lapisan bawah permukaan dua dimensi dengan kontras warna berbeda yang menunjukkan distribusi nilai tahananjenis bawah permukaan. Secara umum struktur batuan bawah permukaan daerah penelitian dapat dibagi menjadi tiga bagian yang berbeda pada arah horizontal (Gambar 4).

Pada struktur batuan bagian pertama (Gambar 4a), lapisan pertama adalah lapisan berwarna hijau 


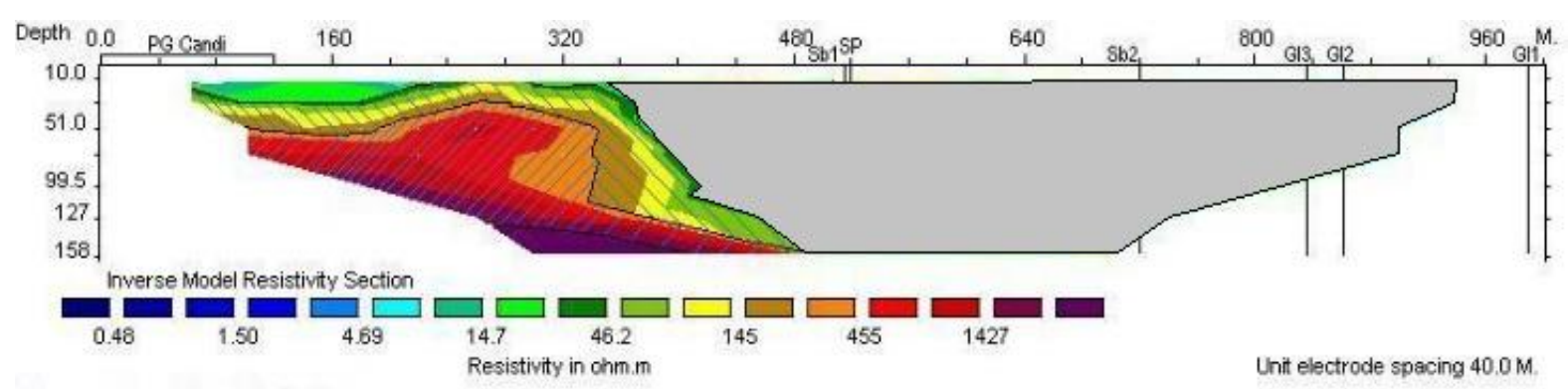

(a) Struktur batuan bagian pertama

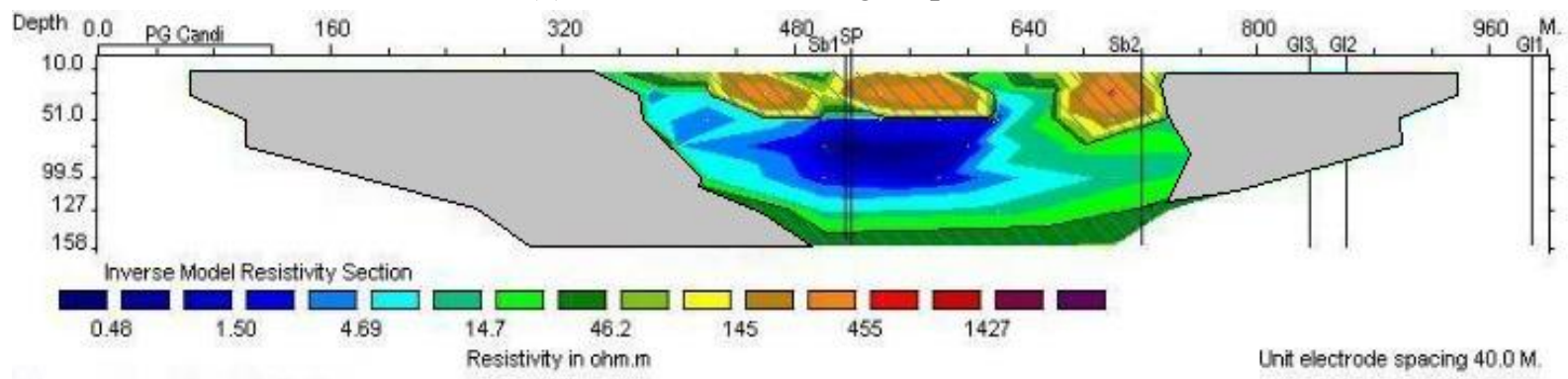

(b) Struktur batuan bagian kedua

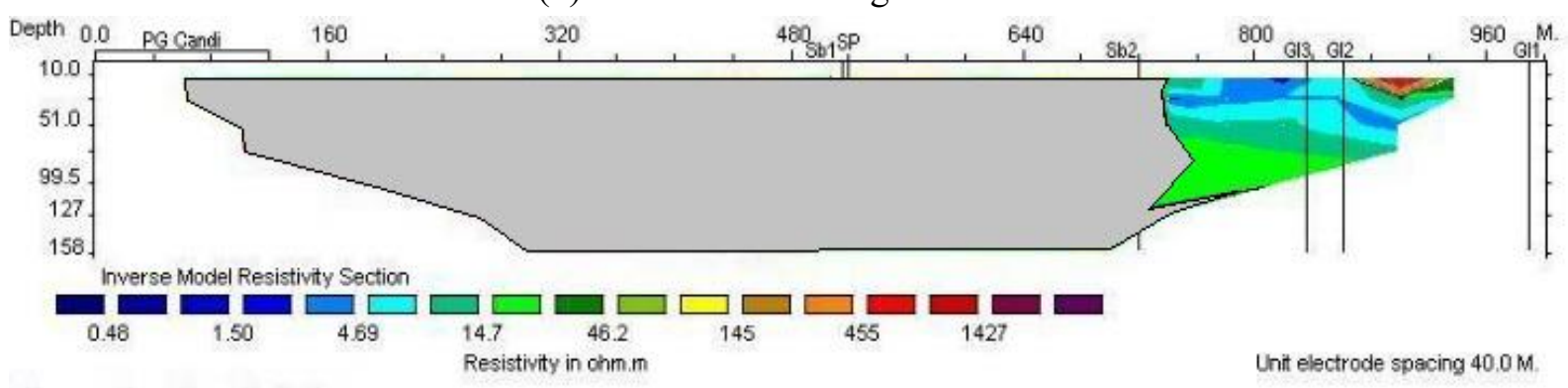

(c) Struktur batuan bagian ketiga

Gambar 4. Struktur batuan bawah permukaan

dengan nilai tahananjenis $14,7-46,8$ ohm-meter pada kedalaman sekitar 10-30 meter yang menunjukkan lapisan lempung dan pasir. Lapisan kedua adalah lapisan warna hijau muda-kuning dengan nilai tahananjenis 95,6-145 ohm-meter pada kedalaman sekitar 30-50 meter yang menunjukkan lapisan lempung pasiran dan pasir. Hasil ini sesuai dengan penelitian sebelumnya, yang menunjukkan bahwa nilai tahananjenis rendah tersebut adalah lapisan lempung, lempung pasiran dan pasir (Mohamaden \& Ehab, 2017), (Kazakis et al., 2016). Lapisan ketiga adalah

Jika dilakukan interpretasi pada satu titik target (titik SP) penampang lapisan bawah permukaan, maka kondisi bawah permukaan berdasarkan kedalamannya dapat digambarkan seperti pada Tabel 1. lapisan warna merah-ungu dengan nilai tahananjenis lebih dari 941 ohm-meter.

Struktur batuan bagian kedua, terdiri dari lapisan batuan berwarna hijau muda-kuning dengan nilai tahananjenis 95,6-145 ohm-meter, lapisan berwarna coklat dengan nilai tahananjenis 300$455 \mathrm{ohm}$-meter, lapisan berwarna biru tua- biru dengan nilai tahananjenis 0,48-9,69 ohm-meter, dan lapisan berwarna hijau dengan nilai tahananjenis 14,7-95,6 ohm-meter. Sedangkan struktur batuan bagian ketiga didominasi lapisan batuan berwarna hijau dengan nilai tahananjenis sekitar 9,69-95,6 ohm-meter. 
Mengacu Tabel 1, kondisi bawah permukaan bisa dibagi menjadi 5 lapisan batuan. Lapisan pertama adalah lapisan lempung pasiran dan pasir pada kedalaman 0-40 meter dengan nilai tahananjenis 95,6-145 ohm-meter. Lapisan kedua adalah lapisan lempung dan pasir dengan kedalaman 41 50 meter dengan nilai tahananjenis 30,5-46,2 ohm-meter. Lapisan ketiga adalah lapisan akuifer air asin pada kedalaman 51-110 meter dengan nilai tahananjenis 0,48-3,1 ohm-meter. Lapisan ke empat adalah lapisan akuifer air payau pada kedalaman $110 \quad-140$ meter dengan nilai tahananjenis 4,69-9,7 ohm-meter. Dan lapisan kelima adalah akuifer air tawar dalam pada kedalaman 140-170 meter dengan nilai tahananjenis 14,7-46,8 ohm-meter.

Hasil interpretasi yang menunjukkan adanya akuifer air pada daerah penelitian, sesuai dengan penelitian sebelumnya yang menyatakan bahwa litologi material lempung dan pasir merupakan batuan penyusun akuifer (Maria, Rusydi, Lestiana, \& Wibawa, 2018).

Dari penampang lapisan bawah permukaan (Gambar 5), dapat diinterpretasikan bahwa akuifer air tawar ditunjukkan dengan lapisan batuan berwarna hijau muda dan tua dengan nilai tahananjenis rendah berkisar antara 14,7 ohmmeter hingga 46,2 ohm-meter. Akuifer ini tersebar secara meluas pada permukaan dari titik pengukuran 60 sampai titik 240, titik 280 sampai 420, titik 470 sampai 520, titik 580 sampai 670, titik 730 sampai 770 . Dengan ketebalan lapisan akuifer tersebut sekitar 40 meter.

Sedangkan lapisan akuifer air asin ditunjukkan dengan lapisan batuan berwarna biru tua dengan nilai tahananjenis sangat rendah antara $0,48 \mathrm{ohm}$ -
Tabel 1. Kondisi bawah permukaan berdasarkan kedalaman pada titik target

\begin{tabular}{|c|c|c|c|}
\hline $\begin{array}{l}\text { Kedala } \\
\text { man } \\
(\mathrm{m})\end{array}$ & Warna & $\begin{array}{c}\text { Tahanan } \\
\text { jenis } \\
\text { (ohm- } \\
\text { meter) }\end{array}$ & $\begin{array}{l}\text { Lapisan } \\
\text { Batuan }\end{array}$ \\
\hline $0-40$ & $\square \square$ & $\begin{array}{c}95,6- \\
145\end{array}$ & $\begin{array}{l}\text { Lempung } \\
\text { pasiran, pasir }\end{array}$ \\
\hline $41-50$ & $\square \square$ & & Lempung, \\
\hline 51-110 & $\square \square$ & 30,5- & pasir \\
\hline & & $\begin{array}{c}46,2 \\
0,48-3,1\end{array}$ & $\begin{array}{l}\text { Lempung, } \\
\text { pasir }\end{array}$ \\
\hline $110-140$ & $\square \square$ & & $\begin{array}{l}\text { (mengandung } \\
\text { air asin) }\end{array}$ \\
\hline \multirow[t]{3}{*}{$140-170$} & $\square \square$ & $4,69-9,7$ & $\begin{array}{l}\text { Lempung, } \\
\text { pasir }\end{array}$ \\
\hline & & $14,7-$ & payau) \\
\hline & & 46,8 & $\begin{array}{l}\text { Lempung, } \\
\text { pasir (akuifer } \\
\text { dalam) }\end{array}$ \\
\hline
\end{tabular}

meter hingga 3,1 ohm-meter. Akuifer air asin terakumulasi pada titik 440 sampai dengan titik 600 dengan kedalaman 51 sampai 110 meter bawah permukaan. Nilai tahananjenis akuifer air asin yang lebih rendah tersebut sesuai dengan penelitian lainnya yang menyatakan bahwa karakteristik dari akuifer air asin ditunjukkan dengan nilai tahananjenis yang sangat rendah (Ayolabi et al., 2013), (Asfahani \& Zakhem, 2013), (Islami, 2011), (Chitea, Georgescu, \& Ioane, 2011), (Fadili et al., 2017), (Hidayat, Darsono, \& Darmanto, 2014). Nilai tahananjenis yang rendah merupakan salah satu efek dari

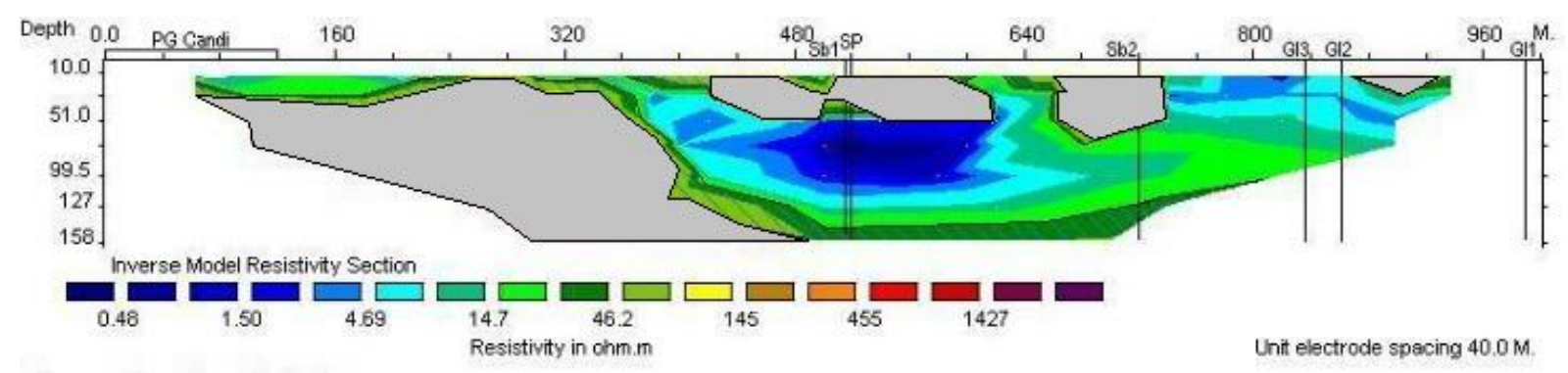

Gambar 5. Sebaran akuifer air asin dan air tawar 
adanya intrusi air asin (Mohamaden \& Ehab, 2017), (Alabjah et al., 2018). Perbedaan nilai tahananjenis tersebut disebabkan karena adanya perbedaan karakteristik antara akuifer air tawar dan akuifer air asin. Akuifer air asin lebih mudah menghantarkan arus listrik dari pada akuifer air tawar, sehingga nilai tahananjenis akuifer air asin lebih rendah daripada nilai tahananjenis akuifer air tawar. Nilai tahananjenis dari akuifer air asin dan air tawar yang dihasilkan sesuai dengan penelitian sebelumnya yang menghasilkan nilai tahananjenis dari akuifer air asin adalah 0,7-3 ohm-meter dan air tawar adalah 30-70 ohm-meter (Goebel et al., 2017), (McInnis et al., 2013).

\section{Interpretasi model bawah permukaan dan data logging}

Interpretasi data geolistrik dan data logging dilakukan dengan membandingkan dan menganalisis kondisi litologi berdasar hasil dari masing-masing data pada satu titik target pengukuran (titik 520) secara vertikal.

Berdasarkan karakteristik litologi pada titik pemboran (Gambar 6), tampak adanya kesesuaian potensi akuifer air asin yang teridentifikasi pada kedalaman 51 sampai 110 meter berdasarkan model tahananjenis dan kedalaman 70 sampai 80 meter berdasarkan data logging. Akumulasi akuifer air asin berada pada kedalaman antara 70 sampai 80 meter, yang ditunjukkan oleh nilai tahananjenis sebesar 0,48 ohm-meter. Sedangkan potensi akuifer air tawar teridentifikasi pada akuifer dalam dengan kedalaman 140 meter sampai 170 meter. Keberadaan akuifer air asin tersebut dapat disebabkan oleh adanya intrusi air laut atau adanya air laut yang terjebak pada lapisan batuan pada saat proses sedimentasi.

\section{KESIMPULAN}

Sidoarjo merupakan daerah dataran rendah yang didominasi oleh endapan permukaan aluvium yang terdiri atas kerikil, pasir, dan lempung. Kondisi hidrogeologinya adalah akuifer produktif sedang dengan penyebaran luas. Interpretasi model tahananjenis dan data logging menunjukkan bahwa akuifer air asin berkisar pada kedalaman 51 sampai 110 meter dan akuifer air tawar berada pada kedalaman 10 sampai 50 meter yang merupakan akuifer air dangkal. Ada pula akuifer air dalam pada kedalaman 140 sampai 170 meter.

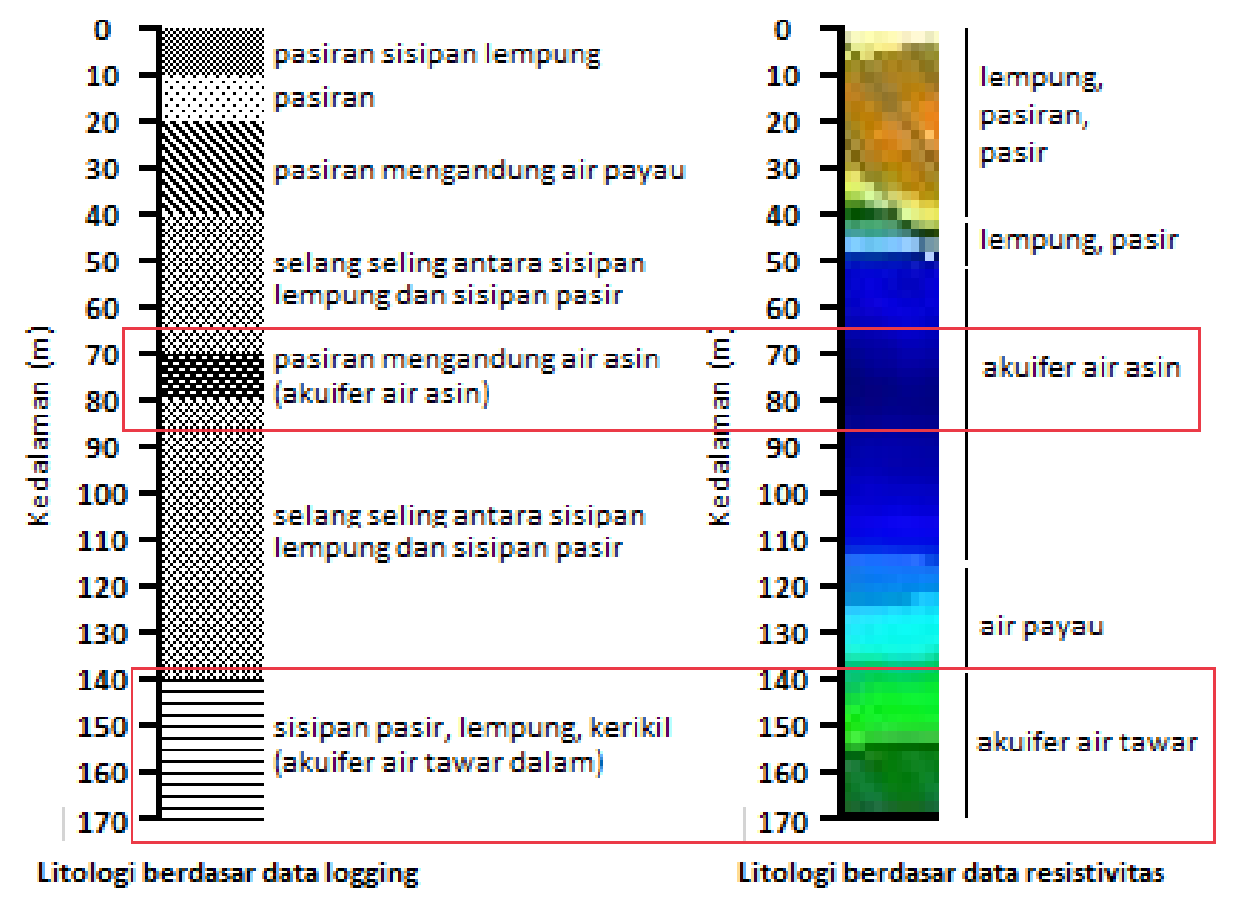

Gambar 6. Kesesuaian karakteristik litologi pada titik target (titik 520) berdasarkan interpretasi dari data logging dan model tahananjenis 


\section{UCAPAN TERIMA KASIH}

Terimakasih kepada Universitas Kanjuruhan Malang atas pendanaan yang diberikan melalui Hibah DIPA LPPM No. 114/C2/1.2/LPPMUK/I.2018.

\section{DAFTAR PUSTAKA}

Alabjah, B., Amraoui, F., Chibout, M., \& Slimani, M. (2018). Assessment of saltwater contamination extent in the coastal aquifers of Chaouia (Morocco) using the electric recognition. Journal of Hydrology.

https://doi.org/10.1016/j.jhydrol.2018.0 9.003

Asfahani, J., \& Zakhem, B. A. (2013). Geoelectrical and Hydrochemical Investigations for Characterizing the Salt Water Intrusion in the Khanasser Valley, Northern Syria, 61(2), 422-444. https://doi.org/10.2478/s11600-0120071-3

Ayolabi, E. A., Folorunso, A. F., Odukoya, A. M., \& Adeniran, A. E. (2013). Mapping saline water intrusion into the coastal aquifer with geophysical and geochemical techniques: the University of Lagos campus case (Nigeria). Springer Plus, 2(1), 433. https://doi.org/10.1186/2193-1801-2433

Benjumea, B., Macau, A., Gabàs, A., \& Figueras, S. (2016). Characterization of a complex near-surface structure using well logging and passive seismic measurements. Solid Earth, 7(2), 685701. https://doi.org/10.5194/se-7-6852016

Boubaya, D. (2017). Combining Resistivity and Aeromagnetic Geophysical Surveys for Groundwater Exploration in the Maghnia Plain of Algeria. Journal of Geological Research, 2017. https://doi.org/http://dx.doi.org/10.1155 /2017/1309053

Budiono, K., Handoko, Hernawan, u, \& Godwin. (2010). Penafsiran Struktur Geologi Bawah Permukaan di Kawasan Semburan Lumpur Sidoarjo ,
Berdasarkan Penampang Ground Penetrating Radar (GPR). Jurnal Geologi Indonesia, 5(3), 187-195.

Chitea, F., Georgescu, P., \& Ioane, D. (2011). Geophysical detection of marine intrusions in Black Sea coastal areas ( Romania ) using VES and ERT data. Geo-Eco-Marina, 17(1).

Dahlin, T, \& Loke, M. H. (1998). Resolution of 2D Wenner resistivity imaging as assessed by numerical modelling. Journal of Applied Geophysics, 38, 237 249.

Dahlin, Torleif, \& Bing, Z. (2004). a Numerical Comparison of 2D Resistivity Imaging With Ten. Geophysical Prospecting, 52, 379-398.

Fadili, A., Najib, S., Mehdi, K., Riss, J., Malaurent, P., \& Makan, A. (2017). Geoelectrical and hydrochemical study for the assessment of seawater intrusion evolution in coastal aquifers of Oualidia, Morocco. Journal of Applied Geophysics. https://doi.org/10.1016/j.jappgeo.2017. 09.020

Goebel, M., Pidlisecky, A., \& Knight, R. (2017). Resistivity imaging reveals complex pattern of saltwater intrusion along Monterey coast. Journal of Hydrology, 551 , 746-755. https://doi.org/10.1016/j.jhydrol.2017.0 2.037

Helaly, A. S. (2017). Assessment of groundwater potentiality using geophysical techniques in Wadi Allaqi basin , Eastern Desert, Egypt - Case study. NRIAG Journal of Astronomy and Geophysics, 6(2), 408-421. https://doi.org/10.1016/j.nrjag.2017.09. 003

Herdyansah, A., \& Rahmawati, D. (2017). Dampak Intrusi Air Laut pada Kawasan Pesisir Surabaya Timur. Jurnal Teknik ITS, 6(2), 599-603.

Hidayat, A. N., Darsono, \& Darmanto. (2014). Interpretasi Salt Water-Fresh Water Zone menggunakan Metode Geolistrik 
Tahananjenis Sukoharjo. JURNAL FISIKA DAN APLIKASINYA, 10(3).

Hodlur, G. K., Dhakate, R., \& Andrade, R. (2006). Correlation of vertical electrical sounding and borehole-log data for delineation of saltwater and freshwater aquifers. GEOPHYSICS, 71(1), G11G20.

Islami, N. (2011). Geoelectrical Resistivity Method For Salt / Brackish Water Mapping, 14(2), 104-114.

Jufriadi, A., \& Ayu, H. D. (2014). Investigation of Landslide Potential by Using Geolistrik Tahananjenis Method in Ampelgading Malang Regency. FOTON, Jurnal Fisika Dan Pembelajarannya, 18(2), 13-18.

Kazakis, N., Pavlou, A., Vargemezis, G., Voudouris, K. S., Soulios, G., Pliakas, F., \& Tsokas, G. (2016). Science of the Total Environment Seawater intrusion mapping using electrical resistivity tomography and hydrochemical data . An application in the coastal area of eastern Thermaikos Gulf , Greece. Science of the Total Environment, 543, 373-387.

https://doi.org/10.1016/j.scitotenv.2015. 11.041

Khan, G. D., Waheedullah, \& Bhatti, A. S. (2013). Groundwater Investigation by Using Resistivity Survey in. Journal of Resources Development and Management, 2, 9-20.

Kitila, G., Lemessa, G., Gebrekidan, H., \& Alamirew, T. (2013). Identification of Groundwater Level by Using Geoelectrical Resistivity Method at Fincha'a Sugar Estate, Blue Nile Basin, Western Ethiopia. STAR Journal, 2(3), 114-125.

Laxmi, G., \& Ramadass, G. (2012). Ground Water Contamination in Granitic Terrain - A Case Study from Katedan , Greater Hyderabad , A . P ., Introduction : International Journal of Pure and Applied Sciences and Technology, 8(1), 15-25.
Loke, M. H. (2013). Tutorial: 2-D and 3-D electrical imaging surveys. Geotomo Software Malaysia. Retrieved from http://seisweb.oma.be/bibadmin/upload s/pdf/COURSENOTES.pdf

Loke, M. H., \& Barker, R. D. (1995). Leastsquares deconvolution of apparent resistivity pseudosections. Geophysics, 60(6), 1682. https://doi.org/10.1190/1.1443900

Maria, R., Rusydi, A. F., Lestiana, H., \& Wibawa, S. (2018). Hidrogeologi dan potensi cadangan airtanah di dataran rendah indramayu. RISET Geologi Dan Pertambangan, 28(2), 181-192. https://doi.org/10.14203/risetgeotam20 18.v28.803

Martorana, R., Capizzi, P., Alessandro, A. D., \& Luzio, D. (2016). Comparison of different sets of array configurations for multichannel 2D ERT acquisition. Journal of Applied Geophysics. https://doi.org/10.1016/j.jappgeo.2016. 12.012

McInnis, D., Silliman, S., Boukari, M., Yalo, N., Orou-pete, S., Fertenbaugh, C., ... Fayomi, H. (2013). Combined application of electrical resistivity and shallow groundwater sampling to assess salinity in a shallow coastal aquifer in Benin , West Africa. Journal of Hydrology, 505, 335-345. https://doi.org/10.1016/j.jhydrol.2013.1 0.014

Metwaly, M., \& Alfouzan, F. (2013). Application of 2-D geoelectrical resistivity tomography for subsurface cavity detection in the eastern part of Saudi Arabia. Geoscience Frontiers, 4(4), 469-476.

https://doi.org/10.1016/j.gsf.2012.12.00 5

Mohamaden, M. I. I., \& Ehab, D. (2017). Application of electrical resistivity for groundwater exploration in Wadi Rahaba, Shalateen, Egypt. NRIAG Journal of Astronomy and Geophysics, 6(1), 201-209. https://doi.org/10.1016/j.nrjag.2017.01. 001 
Novianto, L., \& Nurhayati, I. (2013). Aplikasi WaterCAD untuk Pemodelan dan Simulasi Rencana Pengembangan Layanan Air Bersih Umbulan II Tahun 2022 - Off take Sidoarjo PDAM "Delta Tirta" Kabupaten Sidoarjo. Jurnal Teknik WAKTU, 11(01), 81-92.

Pranata, K. B., Jufriadi, A., Ayu, H. D., \& Wahyuningsih, D. (2016). Penerapan Metode Tahananjenis Untuk Identifikasi Penyebab Rawan Longsor Pada Daerah Aliran Sungai Brantas Kecamatan Sukun Kota Malang. Jurnal Neutrino, $8(2)$, 67-72. https://doi.org/10.18860/neu.v8i2.3311

Shakoor, A., Khan, Z. M., Arshad, M., Farid, H. U., Sultan, M., Azmat, M., ... Hussain, Z. (2017). Regional Groundwater Quality Management through
Hydrogeological Modeling in LCC , West Faisalabad, Pakistan. Journal of Chemistry, 2017.

Utomo, K. S. (2011). Intrusi air laut di kabupaten pemalang. Jurnal Teknik Sipil Dan Perencanaan, 13(2), 141-150.

Wiyono, Lailatin, N., \& Jufriadi, A. (2019). Interpretation Patterns for The Distribution of The Turbidity of Soil Water Around TPA Supit Urang ( Final Removal of Garbage ) Using Geoelectric Resistivity Methods Interpretation Patterns for The Distribution of The Turbidity of Soil Water Around TPA Su. 9th Annual Basic Science International Conference 2019 (BaSIC 2019). https://doi.org/10.1088/1757899X/546/2/022037 